\title{
EFFECT OF ACETYL-L-CARNITINE ON THE INCIDENCE AND THE SEVERITY OF PACLITAXEL- INDUCED PERIPHERAL NEUROPATHY IN CANCER PATIENTS \\ BY
}

Osama Ahmed Badary, PhD a, Lamia Mohamed El Wakeel, PhDa, Mahmoud

Mahmoud Ellithy, MD ${ }^{b}$, Sara Taher Taeb, Bsc ${ }^{c}$

\section{FROM}

(a) Faculty of Pharmacy, Ain Shams University (b) Faculty of Medicine, Ain Shams University (c) Faculty of Pharmacy, Tripoli University

\begin{abstract}
Aim. To evaluate the impact of acetyl-L-carnitine (ALC) administration on the incidence and severity of sensory and motor paclitxel-induced peripheral neuropathy (PIPN) in patients with breast cancer. Methods. Prospective, randomized, controlled study. Patients presenting to the Clinical Oncology Department, Ain Shams University, Cairo, were assessed for eligibility. Forty eligible patients with breast cancer were randomized to one of 2 groups. Control group $(n=20)$ received three cycles of paclitaxel on a weekly dose schedule. Test group received the same regimen plus 1000 mg of oral ALC 3 times/ day for 12 weeks. Baseline evaluation included clinical examination, nerve conduction velocity (NCV) and serum nerve growth factor (NGF) estimation. Incidence and severity of sensory and motor PIPN and treatment related toxicity were assessed after each cycle using the common terminology criteria for adverse events (CTCAE) version 4, (2010). Results. In the ${ }^{1 \text { st }}$ cycle, no significant difference was evident between both groups in frequency of sensory and motor PIPN. In the $2^{\text {nd }}$ cycle and in the $3^{\text {rd }}$ cycle, test group showed a significantly lower frequency of; sensory neuropathy and motor neuropathy versus control. At baseline, the median NGF levels were significantly lower in test group versus control. At the end of the study the median NGF levels were significantly lower in the control group versus their initial baseline levels. While, the test group median levels were higher than their baseline levels. The delta change in NGF was significantly different between the 2 groups. Conclusion Acetyl-1-carnitine administration led to a reduction in the frequency of motor and sensory PIPN, an improvement in NGF levels and was accompanied with less side effects and.
\end{abstract}

\section{INTRODUCTION}

Peripheral neuropathy is a general term indicating the malfunction of peripheral nerves due to various causes (Ocean and Vahdat, 2004; Mielke et al., 2006). Neuropathic pain is defined as "pain arising as a direct consequence of a lesion or disease affecting the somatosensory system" (Treede et al., 2008). These injuries arise 
from different pathological conditions leading to the development of neuropathic pain; such as; chemotherapy-induced peripheral neuropathy (CIPN), paraneoplastic neuropathy, inherited-induced neuropathy, diabetic peripheral neuropathic pain and human immunodeficient virus (HIV)-associated sensory neuropathy (Colleoni and Sacerdote, 2010).

Chemotherapy-induced peripheral neuropathy CIPN is a toxic neuropathy that results from the direct injury of the peripheral nervous system by the chemotherapeutic agent. It frequently complicates the use of several classes of chemotherapeutic agents; taxanes, platinum-based compounds, vinca alkaloids, epothilones and proteasome inhibitors (Walker and Ni, 2007).

The incidence of CIPN ranged widely among various studies anywhere between 10\% and 100\% (Cata et al., 2006; Velasco and Bruna, 2010). Rates may be as high as $60-70 \%$ with taxanes agents frequently used as first and second-line treatment for several common malignancies (Reyes-Gibby et al., 2009; Tanabe et al., 2013).

Chemotherapy-induced peripheral neuropathy CIPN is dose limiting and have negative effects on quality of life and functional capacity. In addition, the onset of CIPN often results in reduced doses of chemotherapy, or discontinuation of therapy altogether, patients are unable to complete full or optimal treatment schedules, likely impacting cancer related outcomes in a negative way (Cata et al., 2006; Argyriou et al., 2012).

Paclitaxel $\left(\right.$ Taxol $\left.^{\circledR}\right)$ is a widely used chemotherapeutic agent derived from Pacific yew tree bark. It is indicated for the treatment of ovarian, breast, non-small cell lung carcinomas and Kaposi's sarcoma (Wani et al., 1971; Velasco and Bruna, 2010; Gornstein and Schwarz, 2014).

The most important dose-limiting side effect of paclitaxel is neurotoxicity (Sahenk et al., 1994). At present, no FDA-approved therapeutic options exist to treat PIPN. Off-label uses of medications remain largely ineffective and/or have debilitating side effects (Gutierrez-Gutierrez et al., 2010; Cunningham et al., 2011).

Acetyl-L-Carnitine (ALC) is the ester acetylated form of carnitine, a well characterized amino acid involved in fatty acid beta-oxidation in mitochondria (Onofrj et al., 2013). Its normal physiological roles in the mitochondria include aiding in the export of acetyl moieties (through acetylation of various compounds) and ensuring the availability of acetyl-CoA through reversal of the enzymatic synthesis reaction (Ghirardi et al., 2005). Animal and clinical studies using ALC have shown that it useful in the prevention and treatment of painful CIPN( Ghelardini et al., 2002; Pisano et al., 2003; Ghirardi et al., 2005; Bianchi et al., 2005; Maestri et al., 2005; Flatters et al., 2006). Acetyl-L-Carnitine ALC has no deleterious effect on the cytotoxicity of paclitaxel when given either concomitantly or sequentially (Engle et al., 2009). In clinical use, ALC is safe and well tolerated (De Grandis, 2007).

Nerve Growth Factor (NGF) was the first neurotrophic factor discovered (LeviMontalcini and Angeletti, 1968). NGF is known to play a crucial role in growth, 
differentiation and survival of specific neuronal population of the peripheral nervous system (Levi-Montalcini, 1987; Colangelo et al., 2008).

Along with the increase in cancer diagnosis, new oncology therapies are discovered as the number of pharmaceutical drugs marketed for cancer continues to grow, increasing complexity in cancer treatment and its associated supportive care (Nystrom and Pick, 2013). The oncology clinical pharmacists' contribution to the safe, effective and cost effective therapeutics is increasingly recognized (Tuffaha et al., 2012).

The current study was designed to assess the impact of administering ALC on the incidence and severity of sensory and motor PIPN in breast cancer Egyptian patients.

\section{PATIENTS \& METHODS:}

Design: prospective randomized controlled study

Setting: Outpatient Clinic of the Clinical Oncology Department, Ain Shams University Hospitals, Cairo, Egypt.

Patients: All breast cancer patients presenting to the Clinical Oncology Department were assessed for eligibility.

\section{Inclusion criteria were:}

Breast cancer patients who were scheduled for a weekly administration of paclitaxel chemotherapeutic regimen, aged between 20-65 years old.

\section{$\underline{\text { Exclusion criteria included patients; }}$}

who have been previously exposed to CIPN, presenting with other co-morbid conditions with risk factors for neuropathies, pregnant or with End Stage Renal Disease (ESRD). Eligible patients were randomly assigned to;

\section{Group A (Control group):}

Twenty patients received paclitaxel on a weekly dose schedule $135 \mathrm{mg} / \mathrm{m}^{2}$. Patients also received placebo oral capsules three times/day, daily throughout the whole three paclitaxel cycles.

\section{Group B ( Test group):}

Twenty patients received paclitaxel on a weekly dose schedule $135 \mathrm{mg} / \mathrm{m}^{2}$. patients also received ALC 1g oral capsules three times/day, daily throughout the whole three paclitaxel cycles. 


\section{METHODS:}

All reported investigations in the current study have been carried out in accordance with the principles of the Declaration of Helsinki as revised in 2000. The ethical committee of Ain Shams University approved the study protocol. All patients were informed of study protocol and only those who gave a written informed consent were enrolled.

\section{A. Baseline Evaluation:}

At enrollment, through a face to face interview, the clinical pharmacist gathered the following information for both groups: a full history including medical, medication, family and social histories, laboratory investigation, full neurological examination including estimation of NCV, baseline education and estimation of NGF levels.

\section{Baseline education:}

For both groups:

- Patients were given the follow up weekly side effects reporting card.

- The follow up weekly card was used for patients' self -assessment and reporting of the frequency and the severity of sensory and motor PIPN/ day during the 12 weeks period. The main signs and symptoms reported were tingling, numbness, muscle weakness, burning sensation, stabbing-like pain, loss of sensation and hypersensitivity to mild painful stimuli.

- Patients were educated about using the follow up card, the expected signs and symptoms and how to report them.

\section{B. Follow up assessment:}

During the 12 weeks period, patients in both groups were assessed weekly as follows;

1. Patient follow-up card assessment and giving new cards.

2. Assessment of frequency and severity of sensory and motor PIPN.

3. Compliance with ALC.

\section{End of study assessment:}

After the 12 weeks of study duration, both groups were assessed for the following;

1. Assessment of frequency and severity of sensory and motor PIPN.

2. Follow up card assessment

3.Neurological examination including NCV examination

3. Adverse events

4. Compliance with ALC. 


\section{Statistical methods}

Data management and analysis were performed using Statistical Package for Social Sciences (SPSS) vs. 17. Numerical data were summarized using means and standard deviations or median \& ranges. Categorical data were summarized as percentages. Comparisons between the two groups were done the Mann-Whitney test. The chi-square test or the Fisher's exact test for small sample size was used to compare between the groups with respect to categorical data. P-values $\leq 0.05$ were considered significant.

\section{RESULTS:}

From the time of November 2012 till December 2013, out of a total of 480 patients, only 40 patients, fulfilled the inclusion criteria and were included in the study. Patients were then randomly assigned to either group A (control) or group B (test).

\section{Baseline Evaluation}

At baseline, both groups were comparable in their baseline parameters with no significant difference between them except NGF levels which were significantly lower in test group versus control group (Table 1).

Table 1 . Patients' demographics and baseline data in both group.

\begin{tabular}{|c|c|c|c|}
\hline Parameter & Control group A $(n=20)$ & Test group $B(n=20)$ & $P$ value \\
\hline Age (yrs); mean \pm S.D & $51.6 \pm 10.8$ & $50.9 \pm 10.8$ & 0.839 \\
\hline $\begin{array}{c}\text { Gender } \\
\text { Male; n }(\%) \\
\text { Female; n }(\%)\end{array}$ & $20(100 \%)$ & $20(100 \%)$ & \\
\hline $\begin{array}{c}\text { Diagnosis } \\
\text { Breast Cancer; n (\%) }\end{array}$ & $20(100 \%)$ & $20(100 \%)$ & \\
\hline $\begin{array}{c}\text { Dose } / \text { cycle }\left(\mathrm{mg} / \mathrm{m}^{2}\right) \\
\text { mean } \pm \text { S.D }\end{array}$ & $183.5 \pm 26.4$ & $180.1 \pm 25.1$ & 0.947 \\
\hline $\begin{array}{c}\text { Regimen } \\
\text { Weekly; n }(\%) \\
\text { Every } 3 \text { weeks; n }(\%)\end{array}$ & $20(100 \%)$ & $20(100 \%)$ & \\
\hline $\begin{array}{c}\text { NGF } ; \text { median (range) } \\
\mathrm{ng} / \mathrm{ml}\end{array}$ & $9.5(1.4-35)$ & $1.9(1.1-20.8)$ & $<0.001 *$ \\
\hline $\begin{array}{c}\text { NCV } \\
\text { Normal; n }(\%) \\
\text { Abnormal; n (\%) }\end{array}$ & $\begin{array}{c}19(95 \%) \\
1(5 \%)\end{array}$ & $\begin{array}{c}20(100 \%) \\
-\end{array}$ & \\
\hline
\end{tabular}

Control group A : patients received paclitaxel + placebo for 12 weeks.

Test group B : patients received paclitaxel + ALC $1 \mathrm{~g}$ t.i.d for 12 weeks.

$* \mathrm{P}$-values $\leq 0.05$ are considered significant. 


\section{PIPN evaluation after intervention}

\section{1- Paclitaxel first cycle:}

No significant difference was evident between the two groups in the frequency of sensory or motor neuropathy or adverse events during the first cycle.

The total number of patients who developed sensory neuropathy during $1^{\text {st }}$ cycle was $27(67.5 \%)$, out of those; $16(80 \%)$ were in the control group versus $11(55 \%)$ were in the test group; $\mathrm{p}=0.091$. The percentage of patients who developed the different grades of sensory neuropathy was as follows; in the control group; $20 \%$ were grade 1 , $45 \%$ were grade 2 and $15 \%$ were grade 3, while in test group, $30 \%$ were grade 1 and $25 \%$ were grade 2 .

The total number of patients who developed motor neuropathy during $1^{\text {st }}$ cycle was $17(42.5 \%)$, out of those; $11(55 \%)$ were in the control group versus $6(30 \%)$ were in the test group; $p=0.110$. The percentage of patients who developed the different grades of motor neuropathy was as follows; in the control group; $50 \%$ developed grade 1 and 5\% developed grade 2, while in test group, 20\% were grade 1 and $10 \%$ were grade 2 (Table 2).

Table 2. The incidence and grade of sensory and motor neuropathy in $1^{\text {st }}$ cycle.

\begin{tabular}{|l|c|c|c|c|}
\hline $\begin{array}{c}\text { Adverse event } \\
\text { n (\%) }\end{array}$ & Control $\mathrm{n}=20$ & Test $\mathrm{n}=20$ & Total $\mathrm{n}=40$ & P-value \\
\hline $\begin{array}{c}\text { Sensory neuropathy; } \\
\text { Grade 1; n (\%) }\end{array}$ & $16(80 \%)$ & $11(55 \%)$ & $27(67.5 \%)$ & 0.091 \\
\hline Grade 2; n (\%) & $9(45 \%)$ & $5(25 \%)$ & $14(35 \%)$ & \\
\hline Grade 3; n (\%) & $3(15 \%)$ & - & $3(7.5 \%)$ & \\
\hline Motor neuropathy; & $11(55 \%)$ & $6(30 \%)$ & $17(42.5 \%)$ & 0.110 \\
\hline Grade 1; $(\%)$ & $10(50 \%)$ & $4(20 \%)$ & $14(35 \%)$ & \\
\hline Grade 2; $\mathrm{n}(\%)$ & $1(5 \%)$ & $2(10 \%)$ & $3(7.5 \%)$ & \\
\hline Grade 3; n (\%) & - & - & - & \\
\hline Total; $\mathrm{n}(\%)$ & $20(100 \%)$ & $20(100 \%)$ & $40(100 \%)$ & \\
\hline
\end{tabular}

Control group A : patients received paclitaxel + placebo for 12 weeks.

Test group B : patients received paclitaxel + ALC $1 \mathrm{~g}$ t.i.d for 12 weeks.

Statistical Test: Chi-square or Fisher's Exact test.

* P-values $\leq 0.05$ are considered significant. 


\section{2- Paclitaxel second cycle:}

In the ${ }^{2 n d}$ cycle, the test group showed a significantly lower frequency of; sensory neuropathy (10 versus $17, \mathrm{p}=0.018$ ) and motor neuropathy ( 3 versus $12, \mathrm{p}=$ $0.003)$ versus control.

The total number of patients who developed sensory neuropathy during $2^{\text {nd }}$ cycle was $27(67.5 \%)$, out of those; $17(85 \%)$ were in the control group versus 10 $(50 \%)$ were in the test group; $\mathrm{p}=0.018$. The percentage of patients who developed the different grades of sensory neuropathy was as follows; in the control group; $5 \%$ were grade 1, $40 \%$ were grade 2 and $40 \%$ were grade 3 , while in test group, $45 \%$ were grade 1 and $5 \%$ were grade 2 .

The total number of patients who developed motor neuropathy during $2^{\text {nd }}$ cycle was $15(37.5 \%)$, out of those; $12(60 \%)$ were in the control group versus $3(15 \%)$ were in the test group; $\mathrm{p}=0.003$. The percentage of patients who developed the different grades of motor neuropathy was as follows; in the control group; 30\% developed grade 1, 25\% developed grade 2 and 5\% developed grade 3, while in test group, $15 \%$ were grade 1 (Table 3 ).

Table 3. The incidence and grade of sensory and motor neuropathy in $2^{\text {nd }}$ cycle.

\begin{tabular}{|c|c|c|c|c|}
\hline $\begin{array}{c}\text { Sensory neuropathy; } \\
\mathrm{n}(\%)\end{array}$ & Control $\mathrm{n}=20$ & Test $\mathrm{n}=20$ & Total $\mathrm{n}=40$ & P-value \\
\hline Grade 1; n (\%) & $1(5 \%)$ & $10(50 \%)$ & $27(67.5 \%)$ & $0.018^{*}$ \\
\hline Grade 2; n (\%) & $8(40 \%)$ & $1(5 \%)$ & $9(22.5 \%)$ & \\
\hline Grade 3; n (\%) & $8(40 \%)$ & - & $8(20 \%)$ & \\
\hline Motor neuropathy; $(\%)$ & $12(60 \%)$ & $3(15 \%)$ & $15(37.5 \%)$ & $0.003 *$ \\
\hline Grade 1; n (\%) & $6(30 \%)$ & $3(15 \%)$ & $9(22.5 \%)$ & \\
\hline Grade 2; n (\%) & $5(25 \%)$ & - & $5(12.5 \%)$ & \\
\hline Grade 3; n (\%) & $1(5 \%)$ & - & $1(2.5 \%)$ & \\
\hline Total; n (\%) & $20(100 \%)$ & $20(100 \%)$ & $40(100 \%)$ & \\
\hline
\end{tabular}

Control group A : patients received paclitaxel + placebo for 12 weeks.

Test group B : patients received paclitaxel + ALC $1 \mathrm{~g}$ t.i.d for 12 weeks.

Statistical Test: Chi-square or Fisher's Exact test.

$*$ P-values $\leq 0.05$ are considered significant. 


\section{3- Paclitaxel third cycle:}

In the $3^{\text {rd }}$ cycle, the test group showed a significantly lower frequency of; sensory neuropathy ( 6 versus $18, \mathrm{p}<0.001)$ and motor neuropathy ( 3 versus $17, \mathrm{p}$ $\mathrm{p}<0.001)$ versus control.

The total number of patients who developed sensory neuropathy during $3^{\text {rd }}$ cycle was $24(60 \%)$, out of those; 18 (90\%) were in the control group versus 6 (30\%) were in the test group; $\mathrm{p}<0.001$. The percentage of patients who developed the different grades of sensory neuropathy was as follows; in the control group; $5 \%$ were grade 1 , $35 \%$ were grade 2 and $50 \%$ were grade 3, while in test group, $30 \%$ were grade 1 . Moreover the total number of patients who developed motor neuropathy during $3^{\text {rd }}$ cycle was $20(50 \%)$, out of those; $17(85 \%)$ were in the control group versus $3(15 \%)$ were in the test group; $\mathrm{p}=0.003$. The percentage of patients who developed the different grades of motor neuropathy was as follows; in the control group; 35\% developed grade $1,45 \%$ developed grade 2 and $5 \%$ developed grade 3, while in test group, $15 \%$ were grade 1 (Table 4).

Table 4. The incidence and grade of sensory and motor neuropathy in $3^{\text {rd }}$ cycle.

\begin{tabular}{|l|c|c|c|c|}
\hline & Control $\mathrm{n}=20$ & Test $\mathrm{n}=20$ & Total $\mathrm{n}=40$ & P-value \\
\hline $\begin{array}{l}\text { Sensory neuropathy; } \\
\mathrm{n}(\%)\end{array}$ & $18(90 \%)$ & $6(30 \%)$ & $24(60 \%)$ & $<0.001^{*}$ \\
\hline Grade 1; $(\%)$ & $1(5 \%)$ & $6(30 \%)$ & $7(17.5 \%)$ & \\
\hline Grade 2; $(\%)$ & $7(35 \%)$ & - & $7(17.5 \%)$ & \\
\hline $\begin{array}{l}\text { Grade 3; }(\%) \\
\mathrm{n}(\%)\end{array}$ & $10(50 \%)$ & - & $10(25 \%)$ & \\
\hline Motor neuropathy; & $17(85 \%)$ & $3(15 \%)$ & $20(50 \%)$ & $<0.001^{*}$ \\
\hline \begin{tabular}{l} 
Grade 1; $(\%)$ \\
\hline Grade 2; $(\%)$
\end{tabular} & $7(35 \%)$ & $3(15 \%)$ & $10(25 \%)$ & \\
\hline Grade 3; $(\%)$ & $1(5 \%)$ & - & $9(22.5 \%)$ & \\
\hline Total; $\mathrm{n}(\%)$ & $20(100 \%)$ & $20(100 \%)$ & $40(100 \%)$ & \\
\hline
\end{tabular}

Control group A : patients received paclitaxel + placebo for 12 weeks.

Test group B : patients received paclitaxel + ALC $1 \mathrm{~g}$ t.i.d for 12 weeks.

Statistical Test: Chi-square or Fisher's Exact test.

$*$ P-values $\leq 0.05$ are considered significant. 


\section{NGF Assessment:}

At baseline, the median plasma NGF levels were significantly lower in the test group $(1.9 ; 1.1-20.8, \mathrm{p}<0.001)$ versus the control $(9.5 ; 1.4-35)$. At the end of the study, the median NGF levels were significantly lower $(2.4, \mathrm{p}=0.02)$ in the control group versus their initial baseline levels, while, the test group median levels were higher than their baseline levels. The delta change in NGF was significantly different between the 2 groups $(\mathrm{p}<0.001)$ (Table 5, Figure 1).

Table 5. Assessment of NGF change in each group and between both groups

\begin{tabular}{|c|c|c|c|}
\hline NGF & Control group A & Test group B & P-value 1 \\
\hline $\begin{array}{l}\text { NGF baseline; } \\
\text { median (range) } \\
(\mathrm{ng} / \mathrm{ml})\end{array}$ & $9.5(1.4-35)$ & $1.9(1.1-20.8)$ & $<0.001 *$ \\
\hline $\begin{array}{l}\text { NGF end; } \\
\text { median (range) } \\
(\mathrm{ng} / \mathrm{ml})\end{array}$ & $2.4(1-32.5)$ & $5.4(1.2-22.5)$ & 0.240 \\
\hline P-value 2 & 0.020* & 0.072 & \\
\hline $\begin{array}{l}\text { NGF Change } \\
\text { median (range) }\end{array}$ & $66.5(-166.7-95.9)$ & $-149.9(-1025-67.4)$ & \\
\hline $\begin{array}{l}\text { NGF Change } \\
\text { NGF baseline } \Rightarrow \text { NGF } \\
\text { end }\end{array}$ & Decreased & Increased & \\
\hline
\end{tabular}

Control group A : patients received paclitaxel + placebo for 12 weeks.

Test group B : patients received paclitaxel + ALC $1 \mathrm{~g}$ t.i.d for 12 weeks.

P-value 1: Difference in NGF between both groups.

P-value 2: Change of NGF with time in each group.

Statistical Test: Mann-Whitney.

* P-values $\leq 0.05$ are considered significant. 


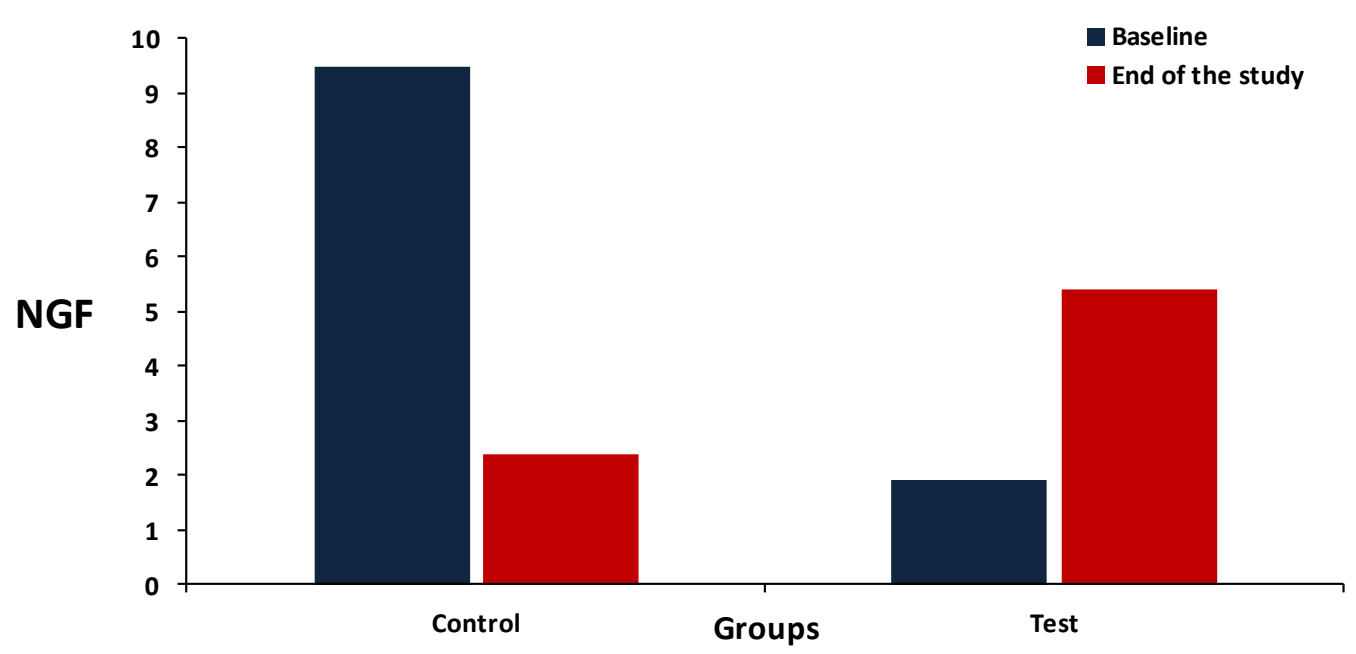

Fig. 1: Median patient NGF plasma levels changes between the two studied groups throughout the study.

Control group A : patients received paclitaxel + placebo for 12 weeks.

Test group B : patients received paclitaxel + ALC $1 \mathrm{~g}$ t.i.d for 12 weeks.

Statistical Test: Mann-Whitney.

* P-values less than 0.05 are considered significant.

\section{Nerve Conduction Velocity:}

The nerve conduction velocity was not significantly different between the 2 groups neither at baseline nor at the end. NCV was normal study for all patients in both groups except one patients in control group.

\section{DISCUSSION:}

Findings of the current study have shown beneficial effect of ALC on PIPN. ALC caused reduction in the frequency and the severity of sensory and motor PIPN in breast cancer patients on weekly paclitaxel chemotherapy. Also ALC administration improved NGF serum levels in the test group patients compared to the control group. Chemotherapy-induced peripheral neuropathy is the most common neurological complication in cancer treatment 1 and probably the most common toxic neuropathy in our environment (Velasco and Bruna, 2010).

The importance of CIPN being a dose-limiting factor (Wolf et al., 2008), a common cause of discomfort that interferes with daily activities, quality of life and survival in patients with cancer and its direct impact on rehabilitation (Cata et al., 2006; Argyriou et al., 2012). 
The oncology clinical pharmacists' contribution to the safe, effective and cost effective therapeutics is increasingly recognized (Tuffaha et al., 2012), yet the role of oncology clinical pharmacists is still underutilized and its outcome was not properly investigated in Egypt.

The current study aimed to evaluate the effect of ALC on PIPN in Egyptian breast cancer patients To our knowledge, this is the first study to investigate the ALC neuroprotective effect in PIPN.

Over the last decade several studies have shown that ALC, a naturally occurring ester of L-carnitine, can be used to protect against and treat painful neuropathies. These studies include neuropathies caused by diabetes, HIV, multi-factorial etiologies and CIPN.

Studies in animal models ( Ghelardini et al., 2002; Pisano et al., 2003; Flatters et al., 2006) and small-scale clinical trials (Bianchi et al., 2005; Maestri et al., 2005) have shown a beneficial effect in using ALC for the treatment of PIPN. Prevention and treatment of PIPN is mandatory as it compromises the quality of life and causes dose reduction or cessation of life saving medication (Argyriou et al., 2012).

The current study has evaluated ALC effect in prevention of PIPN by history and physical examination supported with quantitative assessment via NCV. With specific attention to questions about the symptoms and signs of sensory and motor neuropathy via weekly questionnaire provided by the clinical pharmacist according to CTCAE v.4 (National Institutes of Health, 2010). This questionnaire is composed of signs and symptoms of sensory and motor PIPN and any other adverse events induced by either paclitaxel or ALC. Additionally, the ALC prophylactic role has been explored by assessment of NGF plasma levels.

In the first cycle, both groups showed no significant difference in frequency of sensory or motor neuropathy or adverse events occurrence. In the $2^{\text {nd }}$ cycle, test group showed a significantly lower frequency of sensory neuropathy and motor neuropathy versus control. In the $3^{\text {rd }}$ cycle, test group showed a significantly lower frequency of sensory neuropathy and motor neuropathy versus control. The NCV was not significantly different between 2 groups neither at baseline nor at the end. 
At baseline, the median NGF levels were significantly lower in test group versus control. At the end of the study just before the $4^{\text {th }}$ cycle the median NGF levels were significantly lower in the control group versus their initial baseline levels. While, the test group median levels were higher than their baseline levels. The delta change in NGF was significantly different between the 2 groups.

Our results are consistent with prior preclinical models suggesting that ALC may have neuroprotective effects in PIPN ( Ghelardini et al., 2002; Pisano et al., 2003; Ghirardi et al., 2005; Flatters et al., 2006). As no clinical trial have evaluated the ALC prophylactic effect yet.

Moreover, the results of this current study are in accordance with prior clinical studies that have demonstrated an improvement of previously established PIPN.

Twenty-seven patients with paclitaxel and/or cisplatin-induced neuropathy (according to WHO recommendations for the grading of acute and subacute toxic effects) were enrolled. Patients received at least one cisplatin- $(n=5)$ or one paclitaxel$(n=11)$ based regimen, or a combination of both $(n=11)$. Patients with chemotherapyinduced peripheral neuropathy were treated with ALC $1 \mathrm{~g}$ twice daily by IV infusion over 1-2 $\mathrm{h}$ for at least 10 days. Twenty-six patients were evaluated for response having completed at least 10 days of ALC therapy. At least one WHO grade improvement in the peripheral neuropathy severity was shown in $73 \%$ of the patients. A case of insomnia related to ALC treatment was reported in one patient. ALC was shown to be an effective and well-tolerated agent for the treatment of CIPN (Maestri et al., 2005).

Bianchi et al., 2005 tested oral ALC ( $1 \mathrm{~g}$ tid) for 8 weeks in 25 patients with established paclitaxel- and cisplatin-neuropathy grade $\geq 3$ (CTCAE) (National Institutes of Health, 2010).

during therapy, or grade $\geq 2$ persisting for at least three months after discontinuing the drugs with independent neurologist assessment for patients before and after ALC. All patients except one reported symptomatic relief, and only two described grade 1 nausea. The sensory neuropathy grade improved in 15 of 25 (60\%), and motor neuropathy in 11 of 14 patients (79\%). Total neuropathy score (TNS) that included neurophysiologic measures improved in 23 (92\%). Amelioration of sensory amplitude and conduction velocity (sural and peroneal nerves) was measured in 22 and 
21 patients, respectively. Symptomatic improvement persisted in 12 of 13 evaluable patients at median 13 months after ALC.

In the current study, ALC has not shown evidence of neither tumor potentiation nor deleterious effect on the cytotoxicity of paclitaxel which is in accordance with the results presented in previous studies ( Ghelardini et al., 2002; Pisano et al., 2003; Ghirardi et al., 2005; Engle et al., 2009). Clinically, ALC was ALC is safe and well tolerated (De Grandis, 2007).

Findings of the current study have shown a significant decrease in the plasma NGF levels in the control group and an increased level in the test group versus baseline levels, which could be attributed to the positive effect of ALC on NGF levels via increase in the expression of NGF in the CNS and the transcription rate of the gene coding for the NGF receptor, p75NGFR (Piovesan et al., 1994; Foreman et al., 1995; Onofrj et al., 2013).

\section{Conclusion:}

It can be concluded from the current study, that ALC decreases the frequency and the severity of PIPN. ALC is a tolerable agent with no reported side effects and a favorable patient compliance. CIPN and PIPN are still an unresolved problem as regards its prevention or treatment. Therefore, a new therapeutic approach would have a potential and beneficial role.

\section{REFERENCES:}

Argyriou AA, Bruna J, Marmiroli P, Cavaletti G. (2012). Chemotherapy-induced peripheral neurotoxicity (CIPN): an update. Crit Rev Oncol Hematol 82:51-77.

Bianchi G, Vitali G, Caraceni A, Ravaglia S, Capri G, Cundari S, Zanna C, Gianni L. 2005. Symptomatic and neurophysiological responses of paclitaxelor cisplatin-induced neuropathy to oral acetyl-L-carnitine. Eur J Cancer 41:1746-1750.

Cata JP, Weng HR, Lee BN, Reuben JM, Dougherty PM. (2006). Clinical and experimental findings in humans and animals with chemotherapy-induced peripheral neuropathy. Minerva Anestesiol 72:151-169. 
Colangelo AM, Bianco MR, Vitagliano L, Cavaliere C, Cirillo G, De Gioia L, Diana D, Colombo D, Redaelli C, Zaccaro L, Morelli G, Papa M, Sarmientos P, Alberghina L, Martegani E. (2008). A new nerve growth factor-mimetic peptide active on neuropathic pain in rats. J Neurosci 28:26982709.

Colleoni M, Sacerdote P. (2010). Murine models of human neuropathic pain. Biochim Biophys Acta 1802:924-933.

Cunningham JE, Kelechi T, Sterba K, Barthelemy N, Falkowski P, Chin SH. (2011). Case report of a patient with chemotherapy-induced peripheral neuropathy treated with manual therapy (massage). Support Care Cancer 19:1473-1476.

De Grandis D. (2007). Acetyl-L-carnitine for the treatment of chemotherapy-induced peripheral neuropathy: a short review. CNS Drugs 21 Suppl 1:39-43.

Engle DB, Belisle JA, Gubbels JA, Petrie SE, Hutson PR, Kushner DM, Patankar MS. (2009). Effect of acetyl-1-carnitine on ovarian cancer cells' proliferation, nerve growth factor receptor (Trk-A and p75) expression, and the cytotoxic potential of paclitaxel and carboplatin. Gynecol Oncol 112:631-636.

Flatters SJ, Xiao WH, Bennett GJ. (2006). Acetyl-L-carnitine prevents and reduces paclitaxel-induced painful peripheral neuropathy. Neurosci Lett 397:219-223.

Foreman PJ, Perez-Polo JR, Angelucci L, Ramacci MT, Taglialatela G. (1995). Effects of acetyl-L-carnitine treatment and stress exposure on the nerve growth factor receptor (p75NGFR) mRNA level in the central nervous system of aged rats. Prog Neuropsychopharmacol Biol Psychiatry 19:117-133.

Ghelardini C, Galeotti N, Calvani M, Mosconi L, Nicolai R, Bartolini A. (2002). Acetyl-1-carnitine induces muscarinic antinocieption in mice and rats. Neuropharmacology 43:1180-1187.

Ghirardi O, Lo Giudice P, Pisano C, Vertechy M, Bellucci A, Vesci L, Cundari S, Miloso M, Rigamonti LM, Nicolini G, Zanna C, Carminati P. (2005). Acetyl-L-Carnitine prevents and reverts experimental chronic neurotoxicity induced by oxaliplatin, without altering its antitumor properties. Anticancer Res 25:2681-2687. 
Gornstein E, Schwarz TL. (2014). The paradox of paclitaxel neurotoxicity: Mechanisms and unanswered questions. Neuropharmacology 76 Pt A:175183.

Gutierrez-Gutierrez G, Sereno M, Miralles A, Casado-Saenz E, Gutierrez-Rivas E. (2010). Chemotherapy-induced peripheral neuropathy: clinical features, diagnosis, prevention and treatment strategies. Clin Transl Oncol 12:81-91.

Levi-Montalcini R, Angeletti PU. (1968). Nerve growth factor. Physiol Rev 48:534569.

Levi-Montalcini R. (1987). The nerve growth factor 35 years later. Science 237:11541162.

Maestri A, De Pasquale Ceratti A, Cundari S, Zanna C, Cortesi E, Crino L. (2005). A pilot study on the effect of acetyl-L-carnitine in paclitaxel- and cisplatin-induced peripheral neuropathy. Tumori 91:135-138.

Mielke S, Sparreboom A, Mross K. (2006). Peripheral neuropathy: a persisting challenge in paclitaxel-based regimes. Eur J Cancer 42:24-30.

National Institutes of Health NCI. (2010). Common Terminology Criteria for Adverse Events ( CTCAE) version 4.03. . US department of Health and Human Services, NIH Bethesda, MD.

Nystrom KK, Pick AM. (2013). An oncology pharmacy practice elective course for third-year pharmacy students. Am J Pharm Educ 77:12.

Ocean AJ, Vahdat LT. (2004). Chemotherapy-induced peripheral neuropathy: pathogenesis and emerging therapies. Support Care Cancer 12:619-625.

Onofrj M, Ciccocioppo F, Varanese S, di Muzio A, Calvani M, Chiechio S, Osio M, Thomas A. (2013). Acetyl-L-carnitine: from a biological curiosity to a drug for the peripheral nervous system and beyond. Expert Rev Neurother 13:925-936.

Piovesan P, Pacifici L, Taglialatela G, Ramacci MT, Angelucci L. (1994). Acetyl-Lcarnitine treatment increases choline acetyltransferase activity and NGF levels in the CNS of adult rats following total fimbria-fornix transection. Brain Res 633:77-82.

Pisano C, Pratesi G, Laccabue D, Zunino F, Lo Giudice P, Bellucci A, Pacifici L, Camerini B, Vesci L, Castorina M, Cicuzza S, Tredici G, Marmiroli P, 
Nicolini G, Galbiati S, Calvani M, Carminati P, Cavaletti G. (2003). Paclitaxel and Cisplatin-induced neurotoxicity: a protective role of acetyl-Lcarnitine. Clin Cancer Res 9:5756-5767.

Reyes-Gibby CC, Morrow PK, Buzdar A, Shete S. (2009). Chemotherapy-induced peripheral neuropathy as a predictor of neuropathic pain in breast cancer patients previously treated with paclitaxel. J Pain 10:1146-1150.

Sahenk Z, Barohn R, New P, Mendell JR. (1994). Taxol neuropathy. Electrodiagnostic and sural nerve biopsy findings. Arch Neurol 51:726-729.

Tanabe Y, Hashimoto K, Shimizu C, Hirakawa A, Harano K, Yunokawa M, Yonemori K, Katsumata N, Tamura K, Ando M, Kinoshita T, Fujiwara Y. (2013). Paclitaxel-induced peripheral neuropathy in patients receiving adjuvant chemotherapy for breast cancer. Int J Clin Oncol 18:132-138.

Treede RD, Jensen TS, Campbell JN, Cruccu G, Dostrovsky JO, Griffin JW, Hansson P, Hughes R, Nurmikko T, Serra J. (2008). Neuropathic pain: redefinition and a grading system for clinical and research purposes. Neurology 70:1630-1635.

Tuffaha HW, Abdelhadi O, Omar SA. (2012). Clinical pharmacy services in the outpatient pediatric oncology clinics at a comprehensive cancer center. Int J Clin Pharm 34:27-31.

Velasco R, Bruna J. (2010). [Chemotherapy-induced peripheral neuropathy: an unresolved issue]. Neurologia 25:116-131.

Wani MC, Taylor HL, Wall ME, Coggon P, McPhail AT. (1971). Plant antitumor agents. VI. The isolation and structure of taxol, a novel antileukemic and antitumor agent from Taxus brevifolia. J Am Chem Soc 93:2325-2327.

Wilkes G. (2007). Peripheral neuropathy related to chemotherapy. Semin Oncol Nurs 23:162-173.

Wolf S, Barton D, Kottschade L, Grothey A, Loprinzi C. (2008). Chemotherapyinduced peripheral neuropathy: prevention and treatment strategies. Eur J Cancer 44:1507-1515. 


\section{تقييم تأثير اسيتيل ال كارنيتين على نسبة و حدة حدوث الاعتلال العصبي الطرفي الناجم عن العلاج بالباكليتاكسيل في مرضى هون الأورام}

\section{للسادة الدكاترة}

ا.د أسامة احمد بداري , د. لمياء محم الوكيل1, د. محمود محمود الليثي 2, سارة الطاهر عثمان التائب3

$$
\begin{aligned}
& 1 \text { كلية الصيدلة - جامعة عين شمس }
\end{aligned}
$$

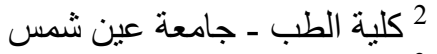

$$
\begin{aligned}
& 3 \text { كلية الصيدلة - جامعة طر ابلس جامع }
\end{aligned}
$$

الاعتلال العصبي الناجم عن العلاج الكيميائي CIPN هو اعنلال عصبي ينتج من إصابة مباشرة في هاي الجهاز العصبي الطرفي بسبب العلاج الكيميائي. باكليتاكسيل هو دواء يستخدم على نطاق واسع في العلاج الكيميائي ,يستعمل لعلاج سرطان المبيض و سرطان الثثي. ينتج عن الاعتلال العصبي الناجم عن باكليتاكسيل قصور في النشاط اليومي للمريض و يسبب خطورة على حياة المريض, و قد يكون مزمن و يصاحب المريض بل

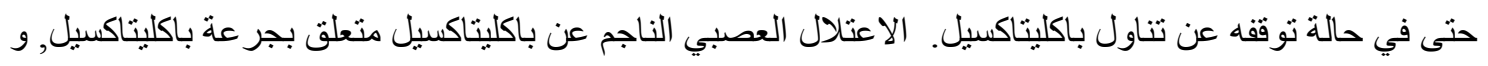

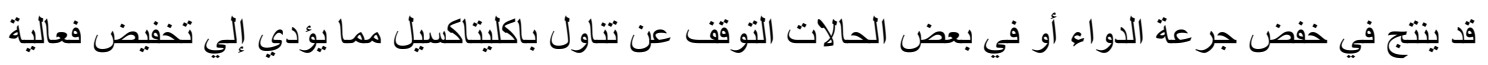
العلاج و البقاء على قبد الحياة. اكتشاف علاجات جديدة للأورام و الزيادة في تشخيص السرطان و عدد العقاقير الصيدلانية المسوقة لعلاج السرطان، كل هذا ادى الى زيادة التعقيد في علاج السرطان و الرعاية الداعمة المرتبطة به. لذلك اصبحت مساهمة صيادلة الاور ام الأكلينيكيين ضرورة ملحة لتحقيق علاجات فعالة آمنة و غير باهظة التكلفة لمرضى الاور ام. وقد أجريت هذه الدراسة على · ؛ من مرضى سرطان الثذي و المترددين على قسم علاج الأورام - مستشفيات جامعة عين شمس - القاهرة - مصر. وقد نم إدراج المرضى عشو ائياً إلى مجمو عنين:المجموعة1 "الضابطة" : أعطي المر 4ضى عقار "باكليتاكسيل" دون آي إضافة. المجموعة2 : أعطي المرضى إنى عقار السرطان "باكليتاكسيل" بالإضافة لعقار اسيتيل-لـكارنيتين للمرضى بجر عة 1000 مجم ثنلاث مرات يوميا عن طريق الفم على مدى ثلاث دورات علاجية اي لمدة إثنى عشر أسبو عاء. المتابعة بواسطة الصيدلي الاكلينيكي

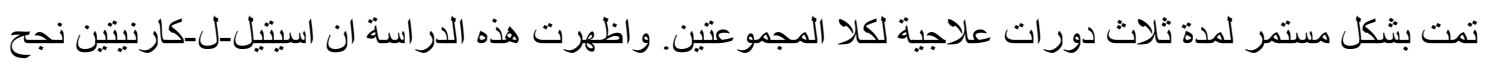
في تقليل مدى حدوث الأعنلال العصبي الناجم عن باكليتاكسيل. كذللك أدى الي تخفيض حدته في حالة حدوثه في

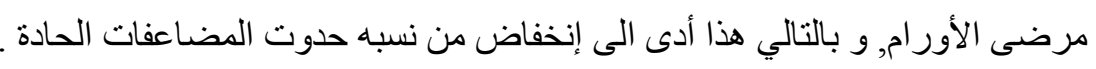

